\title{
Phillips 触媒を用いたエチレン重合における分子量分布および分岐構造の制御因子
}

\author{
外崎 究*1 $\cdot$ 谷池 俊明*1 . 寺野 稔*1
}

（受付 2011 年 2 月 14 日・審査終了 2011 年 3 月 2 日）

\begin{abstract}
要 旨 Phillips 触媒によって合成されるポリエチレン $(\mathrm{PE})$ の特徵的な物性を生み出す分岐構造と分子 量分布が生じる要因を解明することを目的として，実験的および理論的な検討を行った。

重合反応条件および触媒構造の双方の観点より分岐生成量の制御因子について検討したところ, 生成す るPEのメチルおよびブチル以上の分岐構造が，生成するPEの収量に依存することが明らかになり，さ らに in situで生成するコモノマーの挿入が重要であることが示された．とくに，メチル分岐生成に関連 するプロピレンの生成には, クロム種の多核構造が重要であることがわかった。一方, 一様な核構造を有 するモデル触媒上に抢いても広い分子量分布をもつPEを生成し, 分子量分布に対するクロム種の配位環 境の不均一性の寄与が示唆された。このような担体表面の複雑さ故に生じるクロム種の配位環境の分布が 重合特性に与える影響について第一原理計算による検証を行ったところ, 活性クロム種における配位子の 存在およびその位置が，生成するPEの分子量に大きく影響を与え，それにより広い分布を生じることが 明らかになった。
\end{abstract}

\section{1 緒言}

代表的なエチレン重合触媒である Phillips 触媒 $\left(\mathrm{CrO}_{\mathrm{x}} /\right.$ $\mathrm{SiO}_{2}$ ) は短鎖・長鎖の分岐構造および広い分子量分布を 有する高密度ポリエチレン(HDPE)を与え，ポリマーは 特徵的な構造に起因する優れた成形加工性を示す1),2). 工業的に製造される PEの構造は，重合温度などの反応 条件をはじめチタニアやアルミナまたはアルキルアル ミニウムなどの第三化合物の添加によって制御されて いるが，分子レベルで構造を規定するための活性点レべ ルでの因子に関する研究報告はこれまでにほとんど例 がない。

生成するPEの特徵の一つである分岐構造の生成機構 としては，オレフィンメタセシス反応や成長鎖の連鎖移 動反応などによって生成する $\alpha$-オレフィンの再挿入が 主であると考えられているが3)，重合反応中に打的成 長鎖の異性化反応による分岐生成も推定されている ${ }^{2)}$. 広分子量分布は, 触媒活性点の不均一性による活性点ご との成長速度および連鎖移動反応速度の違いによって生 ずるものとされる．触媒表面上には単核，二核および複 核といった核数や，保有するクロムエステル結合数すな わち価数の異なるクロム種が混在することが知られてい

*1 北陸先端科学技術大学院大学マテリアルサイエンス研究 科 (画923-1292 能美市旭台 1-1)
る4). 一方，クロマシロキサン環の大きさ，表面シロキ サン基やシラノール基の配位あるいは反応によって生 ずる構造の不均一性も存在する ${ }^{5)}$. 以上のような活性点 の不均一性はPEの分子量のみならず，分岐構造の起源 となる $\alpha$-オレフィンの生成能にも影響するため，各活 性点の構造と生成する PEの分子量および分岐構造の分 布との相関に対する理解は必須である。このような要求 に対し，制御された活性点構造を有するモデル触媒を設 計し, 活性点構造と触媒特性との相関について検討す ることが最も有用な手段と考えられる.しかしながら， Phillips 触媒においては, 触媒構造のみならず反応中に おける細かな条件までもが分岐の生成量およびその分 布に影響を与えるため，この事実が触媒性能の比較を困 難にしている。したがって，Phillips 触媒より生成する PEの構造の起源に対する活性点レベルでの議論には, 重合条件および触媒構造の双方からの総合的な検討が必 要である.

本研究では, Phillips 触媒によって合成されるPEの 分岐構造および分子量分布の制御因子に関して，重合条 件および触媒構造の両観点より実験的および理論的に検 討を行った。 まず，工業用 Phillips 触媒を用いて，重合 条件が分岐生成に与える影響について検討し，異なる触 媒間の特性を比較する基本的な手段の構築を行った．得 られた知見を基に, 一様な単核あるいは二核のクロム構 造を有するモデル触媒を用いて, Phillips 触媒上のクロ 
ム種の核数の違いが重合特性に与える影響について検討 した．さらにシリカ担体表面の不均一性によって生じる クロム種の配位環境の違いが，重合特性に与える影響に も注目し，密度汎関数計算による検討を行った。

\section{2 実験}

\section{1 試料}

溶媒として用いたペンタンおよびヘプタンは，ベンゾ フェノンケチル法により脱水・脱酸素処理した後, 窒素 気流下で蒸留した。モデル触媒の担体として用いたシ リカは, ES70Xグレード $\left(51 \mu \mathrm{m}, 320 \mathrm{~m}^{2} \mathrm{~g}^{-1}\right)$ をあらか じめ空気下 $823 \mathrm{~K}$ で $1.5 \mathrm{~h}$ 焼成し，減圧下で乾燥させ た。約 $1 \mathrm{wt} .-\%$ のロムが担持された工業用 Phillips 触

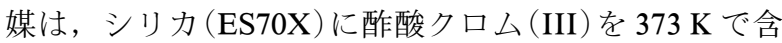
浸させたものを，酸素下 $873 \mathrm{~K}$ で焼成することにより得 られたものを使用した。トリイソブチルアルミニウムは 東ソーファインケムより提供されたものをそのまま使 用した。

\section{2 触媒調製}

クロム種の核数が制御されたモデル触媒は，焼成処理 によって表面ヒドロキシル基濃度が制御されたシリカと $\mathrm{Cr}\left(\eta^{3} \text {-allyl }\right)_{3}$ あるいは $\mathrm{Cr}_{2}\left(\eta^{3} \text {-allyl }\right)_{4}$ の反応を基に，以 下の手順より得た ${ }^{6)}$. 触媒上のクロム種の担持率は誘導 結合プラズマ発光法により定量した

2.2.1 単核構造を有する $(\equiv \mathrm{SiO})_{2} \mathrm{Cr}(=\mathbf{O})_{2}$ 触媒 $\left(\mathbf{C r}_{1}\right)$ の調製

触媒担体 (約 $1.0 \mathrm{~g}$ ) に冷ペンタン $(50.0 \mathrm{~mL})$ および $\mathrm{Cr}\left(\eta^{3} \text {-allyl) }\right)_{3} /$ ペンタン (過剰量)を加え, $273 \mathrm{~K}$ で $30 \mathrm{~min}$ かくはんさせた．万過および真空乾燥後, 得られた粉末 を $860 \mathrm{~K}$ で $30 \mathrm{~min}$ 水素還元し，酸素と $823 \mathrm{~K}$ で $30 \mathrm{~min}$ 反応させることにより単核構造を有する $\mathrm{Cr} / \mathrm{SiO}_{2}$ 系触 媒を黄白色粉末として得た。

2.2.2 二核構造を有する $(\mu-\mathrm{O})\left\{(\equiv \mathrm{SiO}) \mathrm{Cr}(=\mathrm{O})_{2}\right\}_{2}$ 触媒 $\left(\mathrm{Cr}_{2}\right)$ の調製

触媒担体 (約 $1.0 \mathrm{~g})$ にヘプタン $(70.0 \mathrm{~mL})$ 抢よび $\mathrm{Cr}_{2}$ $\left(\eta^{3} \text {-allyl }\right)_{4} /$ ヘプタン (過剰量) を加え, 室温で $30 \mathrm{~min}$ か くはんさせた．万過および真空乾燥後，得られた粉末を $860 \mathrm{~K}$ で $30 \mathrm{~min}$ 水素還元し，酸素と $773 \mathrm{~K}$ で $30 \mathrm{~min}$ 反 応させることにより二核構造を有する $\mathrm{Cr} / \mathrm{SiO}_{2}$ 系触媒 を橙黄色粉末として得た。

\section{3 エチレン重合}

エチレンの重合は, ヘプタン中でトリイソブチルアル ミニウム $1.0 \mathrm{mmol} / \mathrm{L}$ 存在下, エチレン圧 $0.50 \mathrm{MPa}$ で 行った．重合反応は，20-120 mg の触媒をへプタンスラ リーとして系中に導入することで開始し，343-353 K で 15-120 min 行った.

2.4 ポリエチレン分析

$\mathrm{PE}$ の分岐構造の解析は， ${ }^{13} \mathrm{C}\left\{{ }^{1} \mathrm{H}\right\} \mathrm{NMR}$ (Varian Gemi-

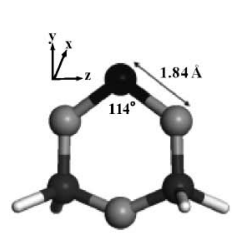

a
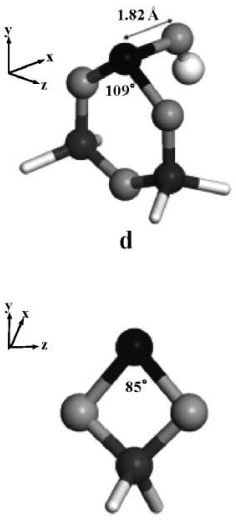
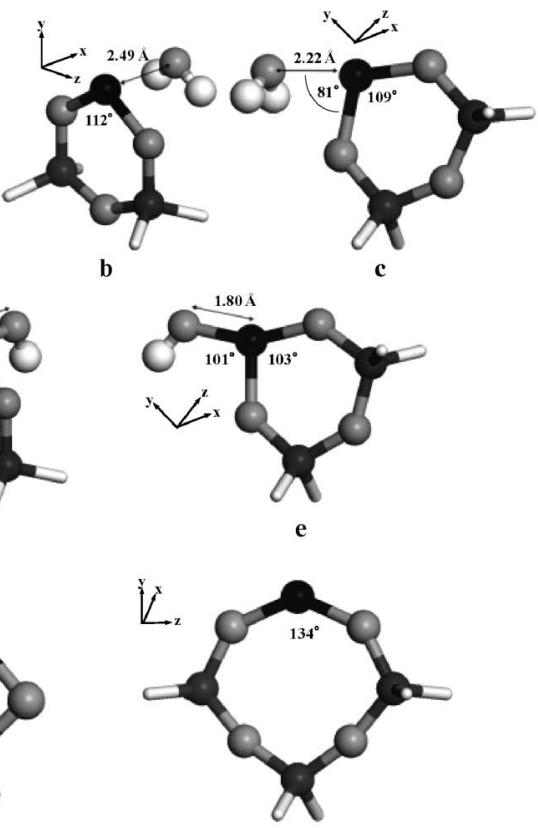

g

Figure 1. Active site models with various coordination environments. Black: $\mathrm{Cr}$, dark gray: $\mathrm{Si}$, gray: $\mathrm{O}$, white: $\mathrm{H}$.

ni-300 spectrometer, $75.46 \mathrm{MHz}$ )により約 $250 \mathrm{mg}$ の PE

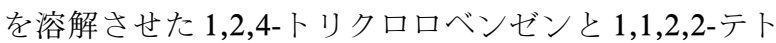

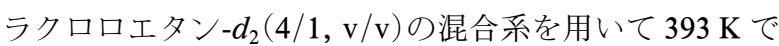
行った. 33.2 および $38.2 \mathrm{ppm}$ に観測されるピークを， それぞれメチル分岐および $n$-ブチル以上の長鎖分岐の

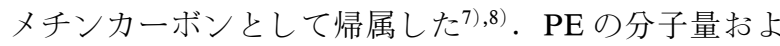
び分子量分布は，ゲル浸透クロマトグラフィー(Waters Alliance GPCV2000CV，カラム：Shodex UT-806 M)を 用い，413 K にて 1,2,4-トリクロロベンゼンを展開溶媒 として測定した.

\section{5 計算手法およびモデル}

密度汎関数計算はプログラム $\mathrm{DMol}^{3}$ により行った。 交換相関汎関数にはPBEを，基底関数には DND およ び有効核ポテンシャルを用いた。構造最適化に打ける収 束条件は，エネルギー変化 $<2.0 \times 10^{-5}$ Hartree および 最大勾配 $<4.0 \times 10^{-3} \mathrm{Hartree} / \AA$ とした。クロム $(\mathrm{IV})$ ， クロム (III) およびクロム (II) は, 高スピン状態でより安 定であった。エチレンの挿入反応抢よび配位エチレンへ の連鎖移動反応に打ける遷移状態計算は，振動数計算を 考慮した構造最適化計算により行った。

クロム種は，表面シロキサン基やシラノール基の配位 あるいは反応によって生じるとされる構造 (二価二配位 の $T_{\mathrm{d}}$, 二価三配位の $O_{\mathrm{h}}$, 三価三配位 $O_{\mathrm{h}}$ )を水分子やヒ ドロキシル基の結合を用いた極限的クラスターモデルで 表現した (Figure 1)，標準モデルには，高活性な活性点 の一つとして推定されている六員環のクロマシロキサ 
ン ${ }^{9), 10)} \mathbf{a}$ を採用した。クロム種の対称性の影響を検討す るために，すべての計算においてクロマシロキサン環を YZ 面で固定した。b-e のモデルの作成に沶いて，水分 子の酸素原子やヒドロキシル基は $\mathbf{b}$ 抢よび $\mathbf{d}$ では $\mathrm{X}$ 軸

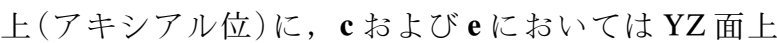
（エクアトリアル）にそれぞれ固定して構造最適化を行っ た、また，クロム種が六員環の骨格を有している限り， 触媒特性がクラスターサイズにほとんど依存しないこと も確認した，一方で，異なるクロマシロキサン環構造を 有する $\mathbf{f}$ および $\mathbf{g}$ に関してもその触媒特性への影響につ いての検討を行った.

Phillips 触媒を用いたエチレン重合に打いて，連鎖移 動反応はおもにエチレンに対して起こることが知られて いる ${ }^{11)}$. 各活性点に打娍長反応抢よび連鎖移動反応 の活性化自由エネルギー $\left(\Delta G_{\mathrm{p}}^{\ddagger}\right.$ 抢よび $\left.\Delta G_{\mathrm{tr}}^{\ddagger}\right)$ を計算し， 式(1)より PEの平均分子量 $\left(M_{\mathrm{n}}\right)$ を求めた.

$$
\frac{M_{\mathrm{n}}}{28.06} \exp \frac{-\left(\Delta G_{\mathrm{p}}^{\ddagger}-\Delta G_{\mathrm{tr}}^{\ddagger}\right)}{R T}
$$

\section{3 結果および考察}

まず，工業用 Phillips 触媒を用いて，重合条件が分岐 生成に与える影響について検討を行った，Figure 2 に重 合時間に対するPEの収量および分岐生成の影響を示 す。PEの収量が重合時間に対して直線性を示し，触媒 活性が定常的な挙動を示していることがわかる。この 時，メチルおよび $n$-ブチル以上の分岐の頻度も同様に 重合時間の経過に伴って増加した．触媒が定常的な挙動 を示す場合，成長反応と異性化反応の速度比は常に一定 であると考えられるので，メチルおよび $n$-ブチル以上 の分岐の頻度が重合時間の経過に伴って増加する現象は 異性化による分岐機構では説明できない。一方，重合反 応によるポリマーの生成の際に $\alpha$-オレフィンが副生 し，重合時間の経過とともに系中の $\alpha$-オレフィン濃度 が増加していると考えると，分岐頻度の経時による増加 は説明可能である，つまり， $\alpha$-オレフィン濃度の低い短 時間重合領域においては分岐生成頻度が少なく， $\alpha$-オレ フィンの生成が十分に起こっている長時間重合反応領域 では多分岐のPEが生成される。そして，更なる長時間 重合領域においては， $\alpha$-オレフィンの生成と消費が平衡 に達し分岐生成頻度の増加が収束挙動を示しているもの と考えられる. Figure 3 に系中の触媒濃度に対する $\mathrm{PE}$ の収量および分岐生成の影響を示す。系中の触媒濃度の 違いにより，メチルおよび $n$-ブチル以上の分岐の頻度 が変化することがわかった．触媒濃度の増加によって， 生成する $\alpha$-オレフィンの生成量も増加し, 結果として 分岐生成の頻度を増加させているものと考えられる。

Figure 2 および 3 の結果から，Phillips 触媒上に打ける

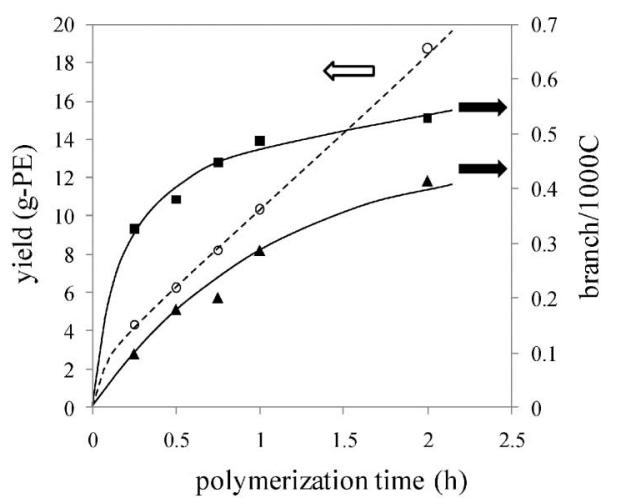

Figure 2. Dependences of the yield $(\bigcirc)$ and branch frequencies (methyl $(\boldsymbol{\square})$ and $\geq n$-butyl $(\boldsymbol{\Lambda})$ ) of PE on the polymerization time with an industrial Phillips catalyst. Catalyst concentration: $2.0 \times 10^{2} \mathrm{mg}$-cat. $/ \mathrm{L}$, polymerization temperature: $343 \mathrm{~K}$, ethylene pressure: $0.5 \mathrm{MPa}$.

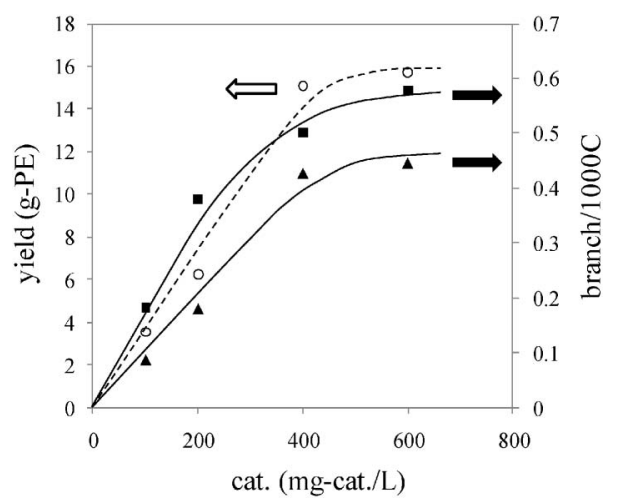

Figure 3. Dependences of the yield $(\bigcirc)$ and branch frequencies (methyl $(\mathbf{\square})$ and $\geq n$-butyl $(\mathbf{\Lambda})$ ) of PE on a catalyst concentration with an industrial Phillips catalyst. Polymerization temperature: $343 \mathrm{~K}$, polymerization time: $30 \mathrm{~min}$, ethylene pressure: $0.5 \mathrm{MPa}$.

分岐生成には $\alpha$-オレフィンの系中濃度が重要であるこ とが示された。 $\alpha$-オレフィンの系中濃度はPEの生成量 に追随して増加するものと推測されるため, Figure 2 お よび 3 における PE の収量を横軸に，分岐頻度を縦軸に して Figure 4 にプロットした。結果として，メチルお よび $n$-ブチル以上の分岐頻度，がそれぞれ PE 収量に対 して一本の曲線で表現できることが明らかになった。こ のほかに重合温度や系中のアルキルアルミニウム濃度が 分岐生成に与える影響について検討を行ったところ，各 条件において収量が分岐頻度に対して $1: 1$ の関係にあ ることがわかった ${ }^{12)}$ 。このように，同一の温度とアルキ ルアルミニウム濃度に打ける PE 収量と分岐頻度の相関 が，異なる触媒間の分岐生成能を比較する指標となり得 ることが示された.

得られた指標を基にクロム種の核数が重合特性に与え 
る影響について検討を行った，検討には単核あるいは二 核構造のクロム種を有するモデル触媒 $\left(\mathrm{Cr}_{1}, \mathrm{Cr}_{2}\right)$ を用い た. $\mathrm{Cr}_{1}, \mathrm{Cr}_{2}$ の両触媒とも工業触媒を凌駕する活性を 示した (Table 1)。これらの触媒によって得られた PE の収量と分岐頻度の相関を Figure 5 に示す. $n$-ブチル以 上の分岐の生成に対してはクロム種の核数の影響は少な かった。一方で $\mathrm{Cr}_{1}$ がメチル分岐の生成能をほとんど示 さないことが明らかとなった． $\mathrm{Cr}_{1}$ において $n$-ブチル以 上の分岐の生成が観測されていることより，単核構造を 有するクロム種は $\alpha$-オレフィンの挿入能を有している はずである，そのため， $\mathrm{Cr}_{1}$ に扔ける低いメチル分岐生 成能は単核種におけるプロピレン生成能の低下に起因し ているものと考えられる. 過去に Terano らはプロピレ ンの生成がオレフィンメタセシス反応を介して起こるこ とを報告した ${ }^{3)}$. しかしながら密度汎関数計算によって 単核構造を有するクロム種上では, 中間体として経由す るメタラサイクル構造が非常に安定であるため, 炭素一 炭素結合切断によるオレフィンの放出過程がエネルギー 的に困難であることが報告されている99,13)。これは Figure 5 の結果と一致を示す． $\mathrm{Cr}_{2}$ に抢いてメチル分岐 生成が促進されていることより，二核種上でオレフィン メタセシス反応が促進されているものと考元られる。二 核種上に打るオレフィンメタセシス反応の推定促進機 構を Scheme 1 に示す.クロムアルキリデン構造が二核 間の架橋構造に変換されることで安定化し, 炭素-炭素

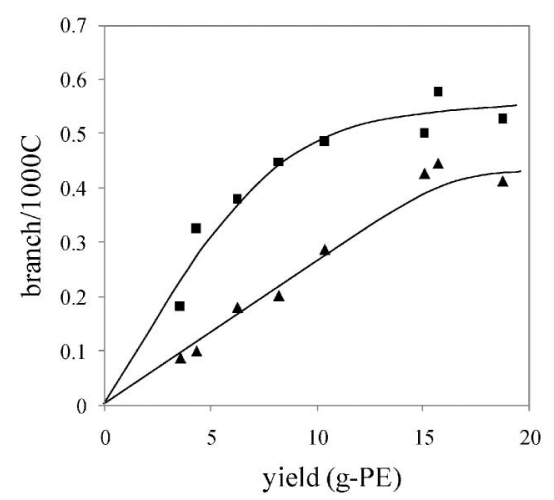

Figure 4. Correlation between the yield and branch frequencies (methyl $(\boldsymbol{\square})$ and $\geq n$-butyl $(\boldsymbol{\Lambda})$ ) of PE.
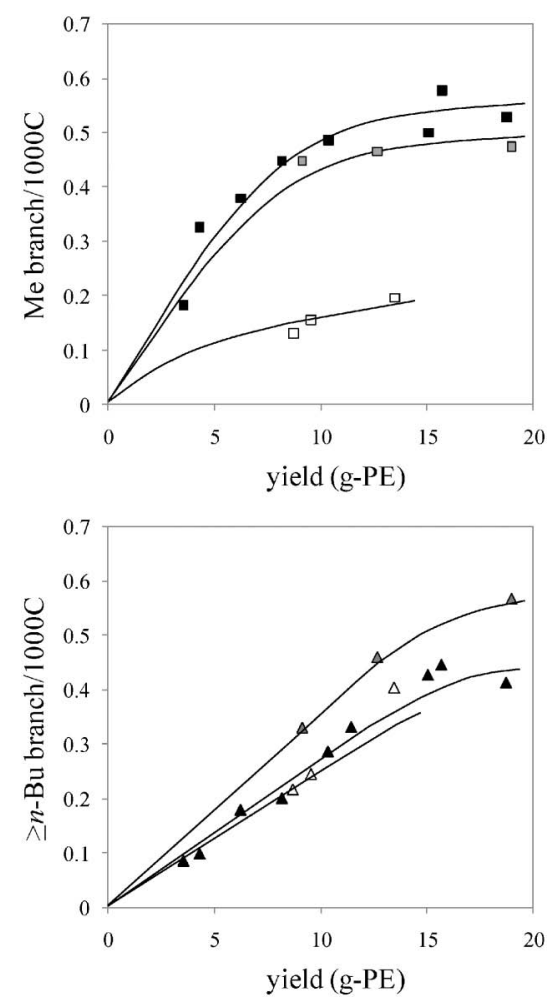

Figure 5. Influence of the chromium nuclearity on branching. Black: industrial Phillips catalyst, white: $\mathrm{Cr}_{1}$, gray: $\mathrm{Cr}_{2}$.

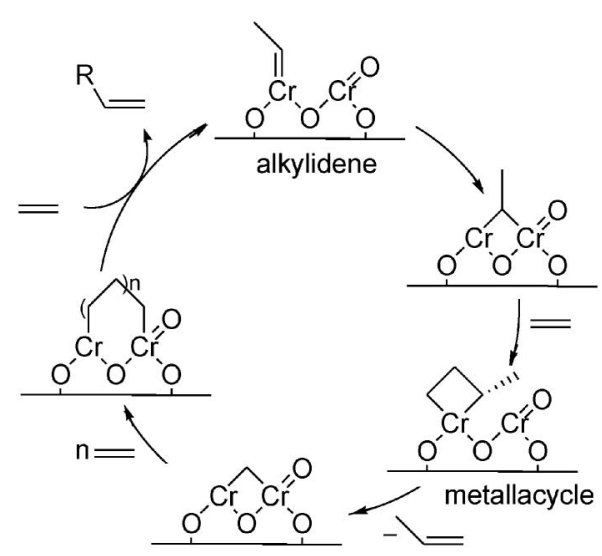

Scheme 1. Plausible mechanism for the enhancement of propylene formation on dinuclear chromium species.

Table 1. Effects of the Cr nuclearity on ethylene polymerization ${ }^{\mathrm{a})}$

\begin{tabular}{ccccccc}
\hline \hline catalyst & $\begin{array}{c}\text { Cr loading } \\
(\text { wt.\% })\end{array}$ & $\begin{array}{c}\text { activity } \\
(\mathrm{kg}-\mathrm{PE} / \mathrm{mol}-\mathrm{Cr} \cdot \mathrm{h})\end{array}$ & $\begin{array}{c}\text { methyl } \\
/ 1000 \mathrm{C}\end{array}$ & $\begin{array}{c}\geq n \text {-butyl } \\
/ 1000 \mathrm{C}\end{array}$ & $M_{\mathrm{n}}$ & $M_{\mathrm{w}} / M_{\mathrm{n}}$ \\
\hline Industrial & 0.91 & $1.8 \times 10^{3}$ & 0.38 & 0.18 & $3.7 \times 10^{4}$ & 22.1 \\
$\mathrm{Cr}_{1}$ & 0.52 & $4.4 \times 10^{3}$ & 0.07 & 0.21 & $2.7 \times 10^{4}$ & 24.2 \\
$\mathrm{Cr}_{2}$ & 0.96 & $2.5 \times 10^{3}$ & 0.45 & 0.33 & $2.8 \times 10^{4}$ & 33.4 \\
\hline
\end{tabular}

a) Catalyst concentration: $2.0 \times 10^{2} \mathrm{mg}$-cat. $/ \mathrm{L}$, polymerization temperature: $343 \mathrm{~K}$, polymerization time: $30 \mathrm{~min}$, ethylene pressure: $0.5 \mathrm{MPa}$. 
結合切断の過程を加速しているのではないかと推定し ている.

Table 1 に示すように, $\mathrm{Cr}_{1}, \mathrm{Cr}_{2}$ ともに一様な核数を 有するにもかかわらず非常に広い分子量分布を有する PEが得られた。過去の Phillips 型のモデル触媒を用い た研究においても, 同様に広い分子量分布を有する $\mathrm{PE}$ が得られることが報告されている14),15). 同一の核数を 有するクロム種であっても，クロマシロキサン環の大き さや表面シロキサン基ないしシラノール基の配位あるい は反応によって不均一性が生じるとされている．このよ うなクロム種の配位環境や対称性の違いが分子量に分布 を与えているものと考え，これらが重合特性に与える影 響について第一原理計算を用いて検討を行った．クロム 種の表面シロキサン基やシラノール基との相互作用は， 水分子やヒドロキシル基の結合で模倣し，活性種には価 数抢よび対称性の異なるモノアルキルクロム (III， IV) を用いた。ジメチルクロム (IV)やクロマシクロペンタ ン (IV)上ではエチレンの配位が起こらず，挿入反応に 対してモノメチルクロム (III) に比べ 13.0 および 24.8 $\mathrm{kcal} / \mathrm{mol}$ 高い活性化エネルギーを示した。 また，この モノメチルクロム上でのエチレンの挿入反応において， アルキル基がクロムエステル結合のトランス位を嫌い， その一方でエチレンの配位がクロムエステル結合のト ランス位を好むことが明らかになった(Scheme 2)。こ のようなトランス影響が配位環境の異なるモノアルキル クロム種の重合特性に多大な影響を与えることを以下 に示す.

Figure 1 に示すさまざまな配位環境を有するモデルを 用い, $n$-プロピルクロム種に対するエチレンの挿入反応 および配位エチレンへの連鎖移動反応の活性化エネル ギー，さらに各モデル上で生成する PEの分子量を算出 した結果を Table 2 に示す．配位子の存在はその電子的 性質や配位位置によらずエチレンの吸着エネルギー $\left(\Delta E_{\mathrm{ad}}\right)$ を立体的に減少させた。 $\mathbf{d}$ の構造においては三つ のクロム酸素結合のトランス位からの反発により，n-プ ロピル基が強くテトラヘドラル方向に押し出されるた め， $\pi$ 錯体形成が阻害され挿入が起こらなかった。 クロ ム- $n$-プロピル結合へのエチレンの挿入反応の見かけ上 の活性化エネルギー $\left(\Delta E_{\mathrm{ap}}\right)$ は $\pi$ 錯体の安定性と大きく 関連しており，吸着エネルギーが減少した各構造におい て活性化エネルギーの増大が観測された。一方，bと とを比較した場合，bでは遷移状態においてクロム一酸 素結合のトランス位にアルキル基が新たに生じることに よる不安定化が起こり， c に比べて $\Delta E_{\mathrm{ap}}$ が大きくなる

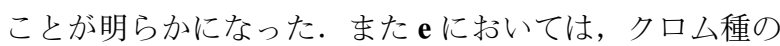
高原子価により遷移状態におけるクロムーアルキル結合 の不安定化が起こっており ${ }^{16)}, \Delta E_{\mathrm{ap}}$ の増加が観測され た. 配位エチレンへの連鎖移動反応に拈いては，エクア
$\bigcup_{\mathrm{L}}$
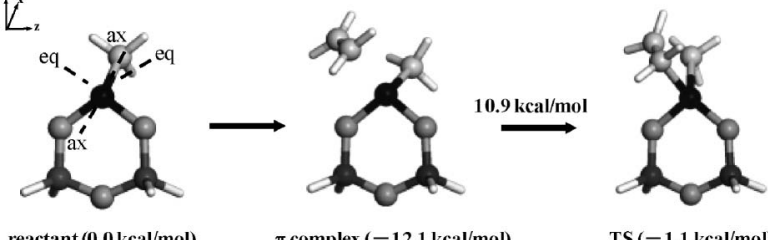

TS (-1.1 kcal/mol)

Scheme 2. Insertion pathway for (a). Black: $\mathrm{Cr}$, dark gray: $\mathrm{Si}$, gray: $\mathrm{O}$, light gray: $\mathrm{C}$, white: $\mathrm{H}$.

Table 2. Effects of coordination environment for activation energies and molecular weight of produced $\mathrm{PE}^{\mathrm{a})}$

\begin{tabular}{|c|c|c|c|c|c|}
\hline \multirow[b]{2}{*}{ model } & \multirow[b]{2}{*}{$\Delta E_{\mathrm{ad}}^{\mathrm{b})}$} & \multicolumn{2}{|c|}{$\Delta E_{\mathrm{ap}}^{\mathrm{c})}$} & \multirow[b]{2}{*}{$\Delta G_{\mathrm{p}}^{\ddagger}-\Delta G_{\mathrm{tr}}^{\ddagger \mathrm{d})}$} & \multirow[b]{2}{*}{$M_{\mathrm{n}}$} \\
\hline & & insertion & $\begin{array}{c}\text { chain } \\
\text { transfer }\end{array}$ & & \\
\hline a & -12.0 & -1.1 & 7.0 & -4.8 & $2.8 \times 10^{4}$ \\
\hline b & -8.2 & 4.3 & 24.2 & -15.0 & $7.0 \times 10^{10}$ \\
\hline c & -8.2 & 0.4 & 6.2 & -2.4 & $8.6 \times 10^{2}$ \\
\hline d & - & 21.3 & - & - & - \\
\hline $\mathbf{e}$ & -7.7 & 4.9 & 6.7 & 0.7 & $\sim 0$ \\
\hline f & -15.4 & -4.4 & 1.6 & -3.2 & $2.7 \times 10^{3}$ \\
\hline g & -8.2 & 0.8 & 8.8 & -6.6 & $3.9 \times 10^{5}$ \\
\hline
\end{tabular}

a) Energies are in $\mathrm{kcal} / \mathrm{mol}$. b) $\Delta E_{\text {ad }}$ is the adsorption energy of ethylene. ${ }^{\text {c) }} \Delta E_{\text {ap }}$ is the apparent activation energy, the height of the transition state from the reactant before $\pi$ complexation. d) $\Delta G_{\mathrm{p}}^{\ddagger}$ and $\Delta G_{\mathrm{tr}}^{\ddagger}$ are the Gibbs energies of activation for the insertion and chain transfer at $350 \mathrm{~K}$.

トリアル位における配位子は $\Delta E_{\mathrm{ap}}$ にほとんど影響を与 えない。一方，アキシアル位に配位子が存在する $\mathbf{b}$ よびdにおいては， $\Delta E_{\text {ap }}$ が大きく増大した．特にdで は安定な遷移状態構造を得ることができなかった．配位 エチレンへの連鎖移動反応では，遷移状態において出発 物質系と生成系のアルキル基およびヒドリドが同時に存 在する．bではこれらを安定化するアキシアル位の一つ が配位子によって既に占有されているため, クロム一酸 素結合のトランス位にアルキル基あるいはヒドリドが強 制され遷移状態が不安定化しているものと考えられる. dでは，唯一のアキシアル位までもがトランス位にクロ ム一酸素結合が存在しているため, 安定な遷移状態を与 えなかったものと考えられる.

エチレンの挿入反応怙よび配位エチレンへの連鎖移動 反応に対する温度の影響を評価するために $\Delta G^{\ddagger}$ の計算 を行った. 工業用 Phillips 触媒を用いたエチレンの重合 温度である $350 \mathrm{~K}$ に掞いて検討を行って得られた $\Delta G_{\mathrm{p}}^{\ddagger}$ 一 $\Delta G_{\mathrm{tr}}^{\ddagger}$ を Table 2 に示す. $\Delta G_{\mathrm{p}}^{\ddagger}-\Delta G_{\mathrm{tr}}^{\ddagger}$ は $\Delta E_{\mathrm{p}}^{\ddagger}-\Delta E_{\mathrm{tr}}^{\ddagger}$ と比べて 1.0-4.6 kcal $/ \mathrm{mol}$ 高い值を示し, エントロピー による影響が連鎖移動反応を相対的に促進することが明 らかになった. しかしその一方で, 各構造間の $\Delta G_{\mathrm{p}}^{\ddagger}-$ $\Delta G_{\mathrm{tr}}^{\ddagger}$ の差は $\Delta E_{\mathrm{p}}^{\ddagger}-\Delta E_{\mathrm{tr}}^{\ddagger}$ の差と同程度であり，配位環境 
の分子量分布への影響はエンタルピー項から生じると いえる.

配位環境の違いによるエチレンの挿入反応および配位 エチレンへの連鎖移動反応に対する影響によって，モノ アルキルクロム $(\mathrm{III})$ は生成する PE の分子量に $8.6 \times 10^{2}$ $-7.0 \times 10^{10}$ の幅を与えることが明らかになった．アキ シアル位からの水の配位は，連鎖移動反応を抑制するこ とで生成する PEの分子量を増加させ，エクアトリアル 位からの配位は分子量を減少させた。一方，表面シロキ サン基やシラノール基などがクロム種に結合しモノアル キルクロム (IV)になると，挿入反応に打ける活性化障 壁の増大，配位エチレンへの連鎖移動反応の過度の促進 などの理由により $350 \mathrm{~K}$ ではポリマー鎖の成長が起こら ないことがわかった。

このように，クロム種の配位環境が生成するPEの分 子量に非常に敏感に作用することが明らかになった。本 研究に用いたモデルは, 実際の触媒系と比較して極度に 対称性が制御されているため配位子の影響が過㮃に反映 されているものと考えられるが，配位環境が PEの分子 量を変化させる大きな因子であることは間違いないとい える，その一方，クロマシロキサン環の大きさの違いが 生成する PEに与える影響は，配位環境に比べ非常に小 さいことがわかった。

\section{4 結 論}

Phillips 触媒によって生成されるポリエチレンの分岐 構造および分子量分布の支配因子に関して実験的および 理論的検討を行った. メチルおよび $n$-ブチル以上の分 岐がいずれもポリエチレンの収量に依存し, in situで生 成する $\alpha$-オレフィンの再挿入が主な分岐生成機構であ ることが示された，単核抢よび二核構造を有するモデル 触媒を用いた検討により，メチル分岐生成に関連するプ ロピレンの生成にはクロム種の多核構造が重要であるこ
とが明らかになった。一方，ポリエチレンの分子量に対 しては，核数の不均一性より配位環境や対称性の不均一 性が大きく影響することが密度汎関数計算によって証明 された。

以上，本研究に打ける検討により，Phillips 触媒にお ける特異な重合性能である分岐生成や広い分子量分布の 起源に関する有用な知見が得られた。これらの知見はポ リエチレンの物性を自在に制御できる新規工業触媒の開 発に大きく貢献するものと期待される.

\section{文献}

1) M. P. McDaniel, Adv. Catal., 33, 47 (1985).

2) E. van Ruymbeke, V. Stéphenne, D. Daoust, P. Godard, R. Keunings, and C. Bailly, J. Rheol., 49, 1503 (2005).

3) B. Liu, H. Nakatani, and M. Terano, J. Mol. Catal. A: Chem., 201, 189 (2003).

4) B. Liu, Y. Fang, and M. Terano, J. Mol. Catal. A: Chem., 219, 165 (2004).

5) B. M. Weckhuysen, I. E. Wachs, and R. A. Schoonheydt, Chem. Rev., 96, 3327 (1996).

6) Y. Iwasawa, Y. Sasaki, and S. Ogasawara, J. Mol. Catal., 16, 27 (1981).

7) W. Liu, D. G. Ray III, and P. L. Rinaldi, Macromolecules, 32, 3817 (1999).

8) G. B. Galland, R. F. de Souza, R. S. Mauler, and F. F. Nunes, Macromolecules., 32, 1620 (1999).

9) Ø. Espelid and K. J. Børve, J. Catal., 195, 125 (2000).

10) C. A. Demmelmaier, R. E. White, J. A. van Bokhoven, and S. L. Scott, J. Catal., 262, 44 (2008).

11) R. Blom, A. Follestad, and O. Noel, J. Mol. Catal., 91, 237 (1994).

12) K. Tonosaki, T. Taniike, and M. Terano, Macromol. React. Eng., in press.

13) R. Schmid and T. Ziegler, Can. J. Chem., 78, 265 (2000).

14) S. L. Scott and J. Amor Nait Ajjou, Chem. Eng. Sci., 56, 4155 (2001).

15) H. Ikeda and T. Monoi, J. Polym. Sci., Part A: Polym. Chem., 41, 413 (2003).

16) K. Tonosaki, T. Taniike, and M. Terano, J. Mol. Catal. A: Chem., 340, 33 (2011).

Elucidation of Control Factors of Molecular Weight Distribution and Branches in Ethylene Polymerization Using Phillips Catalysts Kiwamu Tonosaki*1, Toshiaki TANIIKE*1, and Minoru TERANo*1

${ }^{* 1}$ School of Materials Science, Japan Advanced Institute of Science and Technology (1-1 Asahidai, Nomi 923-1292, Japan)

Comprehensive investigations based on experimental and theoretical approaches were undertaken to elucidate the control factors of branching and broad molecular weight distribution (MWD) in polyethylene (PE) that was obtained using Phillips catalysts. It was found that the branch frequencies in PE are decided by the polymer yield, suggesting a branching mechanism by incorporation of in situ formed $\alpha$-olefins. Investigations on the effects of the chromium nuclearity using model catalysts proved a prominent enhancement in methyl branching on dinuclear chromium species. On the other hand, the model catalysts produced PE with broad MWDs despite the uniform chromium nuclearity. Based on the results, the influence of the coordination environment of chromium, on the molecular weight (MW) of PE was investigated by density functional calculations. The MW of PE produced with monoalkyl-chromium(III) species is significantly sensitive to the coordination environment which is the origin of the broad MWD using Phillips catalysts.

KEY WORDS Phillips Catalyst / Chain Branch / Molecular Weight Distribution / Polymerization / Polyethylene (PE) /

(Received February 14, 2011: Accepted March 2, 2011)

[Kobunshi Ronbunshu, 68, 326-331 (2011)]

(C)2011, The Society of Polymer Science, Japan 